\title{
Reduced $\beta$-Adrenergic Receptor Activation Decreases G-Protein Expression and $\beta$-Adrenergic Receptor Kinase Activity in Porcine Heart
}

\author{
Peipei Ping, Ramona Gelzer-Bell, David A. Roth, Dan Kiel, Paul A. Insel, and H. Kirk Hammond \\ Veteran's Affairs Medical Center-San Diego and Department of Medicine, University of California, San Diego, \\ San Diego, California 92161
}

\begin{abstract}
To determine whether $\beta$-adrenergic receptor agonist activation influences guanosine $5^{\prime}$-triphosphate-binding protein (G-protein) expression and $\beta$-adrenergic receptor kinase activity in the heart, we examined the effects of chronic $\beta_{1}$ adrenergic receptor antagonist treatment (bisoprolol, 0.2 mg/kg per d i.v., 35 d) on components of the myocardial $\boldsymbol{\beta}$-adrenergic receptor-G-protein-adenylyl cyclase pathway in porcine myocardium. Three novel alterations in cardiac adrenergic signaling associated with chronic reduction in $\beta$-adrenergic receptor agonist activation were found. First, there was coordinate downregulation of $\mathrm{Gi}_{2}$ and Gs $\alpha$ mRNA and protein expression in the left ventricle; reduced G-protein content was also found in the right atrium. Second, in the left ventricle, there was a twofold increase in $\beta$-adrenergic receptor-dependent stimulation of adenylyl cyclase and a persistent high affinity state of the $\beta$-adrenergic receptor. Finally, there was a reduction in left ventricular $\beta$-adrenergic receptor kinase activity, suggesting a previously unrecognized association between the degree of adrenergic activation and myocardial $\boldsymbol{\beta}$-adrenergic receptor kinase expression. The heart appears to adapt in response to chronic $\beta$-adrenergic receptor antagonist administration in a manner that would be expected to offset reduced agonist stimulation. The mechanisms for achieving this extend beyond $\beta$-adrenergic receptor upregulation and include alterations in G-protein expression, $\beta$-adrenergic receptor-Gs interaction, and myocardial $\beta$-adrenergic receptor kinase activity. (J. Clin. Invest. 1995. 95:1271-1280.) Key words: adrenergic signaling $\bullet \beta$-adrenergic receptor antagonist • heart failure $\bullet$ adenylyl cyclase
\end{abstract}

\section{Introduction}

$\beta$-Adrenergic receptor antagonists are used in the treatment of angina pectoris, hypertension, and heart failure. As agents that interfere with $\beta$-adrenergic receptor stimulation, it is reasonable to propose that these agents may affect the expression and interaction of myocardial signal-transducing elements in the $\beta$-adrenergic receptor-responsive adenylyl cyclase pathway. Clini-

Address correspondence to H. Kirk Hammond, M.D., VAMC-San Diego (111-A), 3350 La Jolla Village Drive, San Diego, CA 92161. Phone: 619-552-8585 (3552); FAX: 619-552-7490. email: khammond@ ucsd.edu. D. A. Roth's present address is the Department of Kinesiology, University of Colorado, Boulder, CO 80302.

Received for publication 24 May 1994 and in revised form 7 October 1994.

The Journal of Clinical Investigation, Inc.

Volume 95, March 1995, 1271-1280 cal and experimental data suggest that chronic administration of $\beta$-adrenergic receptor antagonists affects cell surface $\beta$-adrenergic receptor number and physiological responsiveness in the heart (1). However, the mechanisms by which elements of the $\beta$-adrenergic receptor-adenylyl cyclase pathway are altered by such treatment and the nature of these alterations remain to be firmly established. Two elements that have received little previous attention but are likely to provide important insights into mechanisms for altered transmembrane signaling in the setting of reduced $\beta$-adrenergic receptor activation are myocardial guanosine $5^{\prime}$-triphosphate (GTP) ${ }^{1}$-binding protein (Gprotein) expression and $\beta$-adrenergic receptor kinase activity. G-proteins transduce signals from $\beta$-adrenergic receptors to effectors such as adenylyl cyclase and calcium channels, whereas $\beta$-adrenergic receptor kinase participates in receptor desensitization by catalyzing phosphorylation of agonist-occupied receptors (2).

Previous studies from our laboratory and others have shown that sustained $\beta$-adrenergic receptor activation can influence the expression of not only cell surface $\beta$-adrenergic receptors, but also $\mathrm{Gs}$ and $\mathrm{Gi}$ in the heart (3-20). Heart failure, a condition characterized in part by systemic neurohumoral adrenergic activation, is associated with reduced $\beta$-adrenergic receptor expression at mRNA and protein levels $(4,5,15-17)$ and, in some studies, with alterations in the expression of cardiac G-proteins $(4,7,8,13,18)$. Recent studies have shown that chronic isoproterenol infusion is associated with increased cardiac $\mathrm{Gi} \alpha_{2}$ content, possibly resulting from increased $\mathrm{Gi} \alpha_{2}$ mRNA transcription rates (11). Data from these studies, acquired from diverse pathophysiological models, provide evidence that G-proteins, similar to $\beta$-adrenergic receptors, are susceptible to regulation in the heart in a manner that may reflect adrenergic activation.

It was recently reported that $\beta$-adrenergic receptor kinase activity is increased in failing left ventricles obtained from humans with heart failure $(17,21)$. Based on these studies and others alluded to previously, we have asked whether signaltransducing elements such as G-proteins and $\beta$-adrenergic receptor kinase may be altered in a manner dependent upon the extent of $\beta$-adrenergic receptor agonist activation. We therefore treated pigs for $35 \mathrm{~d}$ with the $\beta_{1}$-adrenergic receptor antagonist bisoprolol (22) to determine the effects of reduced $\beta$-adrenergic receptor activation upon cardiac G-protein expression and $\beta$ adrenergic receptor kinase activity. We tested the hypothesis that, in left ventricular myocardium, reduced $\beta$-adrenergic receptor agonist activation would be associated with altered expression of G-proteins and reduced $\beta$-adrenergic receptor kinase activity.

1. Abbreviations used in this paper: G-protein, guanosine 5'-triphosphate-binding protein; GST, glutathione- $S$-transferase; ICYP, iodocyanopindolol. 


\section{Methods}

Animals. 12 pigs (Sus scrofa), $50 \pm 8 \mathrm{~kg}$ (mean \pm 1 SEM) were used for the study. After acclimatization to human handling, animals received ketamine $(50 \mathrm{mg} / \mathrm{kg}$, i.m.) and atropine sulfate $(0.1 \mathrm{mg} / \mathrm{kg}$, i.m.) followed by sodium amytal ( $100 \mathrm{mg} / \mathrm{kg}$, i.v.). Animals underwent endotracheal intubation, and halothane $(0.5-1.5 \%)$ was delivered by a pressurecycled ventilator for the duration of the surgical procedure. Left thoracotomy was performed and catheters were placed in the aorta and pulmonary artery. Six pigs were randomly selected to receive daily bisoprolol treatment. The remaining six pigs served as controls. The protocol was in accordance with the National Institutes of Health guidelines for the use of animals in research and was approved by the animal use committee at the Veteran's Affairs Medical Center, San Diego, and the University of California, San Diego.

Bisoprolol treatment and heart rate responses. $2 \mathrm{wk}$ after recovery from surgery, the six animals that were to receive bisoprolol underwent pharmacological testing to determine heart rate responsiveness. Two strategies were used. First, we measured basal heart rate $30 \mathrm{~min}$ after cholinergic receptor blockade with glyocopyrrolate $(0.14 \mathrm{mg} / \mathrm{kg}$, i.v. $)$, a long-acting muscarinic cholinergic antagonist. The dose of glycopyrrolate was selected from pilot studies; the absence of changes in heart rate in response to nitroglycerine-induced hypotension was used as a criterion for successful suppression of vagally mediated heart rate modulation. By removing the influence of acetylcholine on sinoatrial node phase 4 depolarization, heart rate should more directly reflect the influence of sinoatrial node $\beta$-adrenergic receptor responsiveness. We then administered bolus intravenous doses of isoproterenol until a maximal heart rate was achieved. After these studies were completed, animals received bisoprolol $(0.2 \mathrm{mg} / \mathrm{kg}$ per d, i.v.) for the remainder of the study ( $35 \pm 2$ d). The pharmacological tests were repeated 5-7 d after the initiation of treatment to document decreased heart rate responsiveness attributable to bisoprolol. Studies were then repeated just before the animals were killed. The detailed methodology can be found elsewhere $(4,23)$.

Terminal surgery. After $35 \pm 2 \mathrm{~d}$, animals were anesthetized and intubated, and midline sternotomies were performed. The heart was removed and rinsed in sterile saline $\left(4^{\circ} \mathrm{C}\right)$, and the coronary arteries were rapidly perfused with sterile saline $\left(4^{\circ} \mathrm{C}\right)$. Right atrial samples were obtained from identical regions in all animals. Transmural samples of left ventricular free wall were taken midway from base to apex, near the midportion of the left anterior descending coronary artery. Myocardial samples were then frozen $\left(-80^{\circ} \mathrm{C}\right)$. The time from heart removal to placing samples in liquid nitrogen was $5-10 \mathrm{~min}$.

Membrane preparation. Frozen $\left(-80^{\circ} \mathrm{C}\right)$ transmural samples were powdered in a stainless steel mortar and pestle $\left(-80^{\circ} \mathrm{C}\right)$, placed in Tris buffer, and glass-glass homogenized. To assess adenylyl cyclase activity, the pellet of a 45,000- $g$ centrifugation was resuspended in buffer and adenylyl cyclase studies were performed. For radioligand binding experiments, contractile proteins were extracted $(0.5 \mathrm{M} \mathrm{KCl}$, $20 \mathrm{~min}, 4^{\circ} \mathrm{C}$ ) before the first centrifugation.

$\beta$-Adrenergic receptor binding studies. $\beta$-Adrenergic receptors were identified using the radioligand $\left[{ }^{125} I\right]$ iodocyanopindolol (ICYP; 5-700 $\mathrm{pM}$ ) in saturation isotherm experiments conducted on crude membrane preparations as previously described $(4,23) . \beta_{1^{-}}$and $\beta_{2}$-adrenergic receptor numbers were determined in competition binding experiments using the selective $\beta_{2}$-adrenergic receptor antagonist ICI 118,551 $\left(10^{-10}-10^{-4} \mathrm{M}\right)$ as previously described (4). To evaluate adverse effects caused by retained bisoprolol, studies were repeated after multiple resuspensions and centrifugations $(n=2)$; receptor quantification was unaffected. The affinity constants for ICYP and (-)-isoproterenol were similar in myocardium from control and bisoprolol-treated pigs, a result that strongly suggests the absence of bisoprolol in the membrane homogenates. Nevertheless, all membrane preparations for these experiments underwent a minimum of two centrifugations and resuspensions.

Determinations of the $K_{\mathrm{i}}$ for isoproterenol and the proportion of $\beta$ adrenergic receptors displaying high or low affinity binding (an assessment of the degree to which $\beta$-adrenergic receptors are coupled with Gs) were performed in competition binding experiments by incubating
$100 \mathrm{pM}$ ICYP with $10^{-10}-10^{-4} \mathrm{M}(-)$-isoproterenol with and without nonhydrolyzable GTP analogs ( $100 \mu \mathrm{M}$ Gpp [ NH]p or $100 \mu \mathrm{M}$ guanosine $5^{\prime}$-O-(thiotriphosphate) $[\mathrm{GTP} \gamma \mathrm{S}]$ ) as previously described (4). Protein concentrations were determined by the method of Bradford (24). Previous experiments have established that $\beta$-receptors are not lost to the supernatant in our membrane preparations and that $\beta$-adrenergic receptor number is unaffected by thoracotomy alone $(4,14)$.

Adenylylcyclase assays. Methods were modified from those of Salomon et al. (25) as previously described $(4,14)$. The following agents were used to stimulate cAMP production (final concentrations): (-)isoproterenol $(10 \mu \mathrm{M})$, GTP $(100 \mu \mathrm{M})$ GTP $\gamma \mathrm{S}(100 \mu \mathrm{M}), \mathrm{AF}(100$ $\mu \mathrm{M})$, and forskolin $(100 \mu \mathrm{M})$. We found that cAMP production under these conditions was linear with respect to time and protein concentration and that 3-isobutyl-2-methylxanthine $(1.0 \mathrm{mM})$, adenosine deaminase $(5 \mathrm{U} / \mathrm{ml})$, or both had no effect on basal or maximally stimulated cAMP production. Previous experiments established that adenylyl cyclase activity does not distribute to the supernatant of a 45,000- $g$ centrifugation in our membrane preparation and that thoracotomy alone does not influence adenylyl cyclase activity (4).

Quantification of Gs $\alpha$ and $\mathrm{Gi \alpha}_{2}$ by immunoblotting. Assessment of $\alpha \mathrm{s}$ and $\alpha \mathrm{i}_{2}$ subunits of $\mathrm{Gs}$ and $\mathrm{Gi} \alpha_{2}$ was conducted using standard SDS-PAGE and immunoblotting techniques $(5,20)$. Briefly, $100 \mu \mathrm{g}$ of protein from each supernatant and resuspended pellet fraction of a $45,000-g$ centrifugation of crude myocardial homogenate derived from appropriate transmural samples was electrophoresed on a $10 \%$ denaturing gel for $4 \mathrm{~h}$ at $30 \mathrm{~mA}$ constant current. For quantification of cardiac $\alpha$ subunits, glutathione-S-transferase (GST; $26.5 \mathrm{kD}$ ) - G $\alpha$ subunit fusion protein expression vectors were constructed with pGEX-3X (Pharmacia LKB, Piscataway, $\mathrm{NJ}$ ) and partial cDNA sequences that corresponded to the carboxyl terminus of the G-proteins (fragment 7, F7). These proteins were expressed in Escherichia coli strain NM522, and the resulting fusion proteins (GST-GsF7 and GST- $\mathrm{Gi}_{2} \mathrm{~F} 7 ; 31 \mathrm{kD}$ and 30 $\mathrm{kD}$, respectively) were purified, quantified (26), and used at four different dilutions per gel for standard curve generation. Low molecular weight standards were also included on each gel. Proteins were electroblotted onto nitrocellulose membranes (Amersham, UK) for $14 \mathrm{~h}$ at $70 \mathrm{~V}, 4^{\circ} \mathrm{C}(27)$. Transfer efficiency was recorded by photocopies of membranes dyed with reversible Ponceau staining, and gel retention was checked with Coomassie blue staining. Background blocking was accomplished by incubating membranes in Tris-buffered saline (TBS, $\mathrm{pH} 7.5$ ) with $2 \%$ nonfat dry milk for $2 \mathrm{~h}$ at $25^{\circ} \mathrm{C}$. Purified primary polyclonal antibodies (New England Nuclear, Boston MA; rabbit antiG-proteins: RM/ 1 for Gs $\alpha$; AS/7 for transducin, Gi $\alpha_{1}$, and $\mathrm{Gi} \alpha_{2}$ ) were diluted 1:600 in $15 \mathrm{ml}$ of TBS with $0.05 \%$ Tween 20 (TTBS; pH 7.5) and $1 \%$ nonfat dry milk, and membranes were incubated for $14 \mathrm{~h}$ at $4^{\circ} \mathrm{C}$ (27). Autoradiographic detection of bands was performed by incubating membranes in $75 \mathrm{ml}$ of TTBS with $1 \%$ nonfat dry milk and $15 \times 10^{8}$ cpm ${ }^{125}$ I-labeled protein A (New England Nuclear) for $2 \mathrm{~h}$ at $25^{\circ} \mathrm{C}$ followed by thorough sequential washes in TTBS, and placing against x-ray film (X-Omat AR, Eastman Kodak Co., Rochester, NY) for $5 \mathrm{~d}$ at $-70^{\circ} \mathrm{C}$. The $45-$ and $31-\mathrm{kD}$ bands for Gs $\alpha$ and GST-GsF7 were removed from the membranes with background controls for gamma counting. Likewise, the 39- and $42.5-\mathrm{kD}$ bands for Gi $\alpha_{2}$, and GST$\mathrm{Gi} \alpha \mathrm{F} 7$ were removed and counted. Using the specific activity of the GST fusion protein standards and the specific activity of the sample bands of interest, we calculated the tissue G-protein content. Gs $\alpha$ and Gi $\alpha_{2}$ cDNAs were provided by Dr. A. Gilman (Texas Health Sciences Center, Dallas, TX) and Dr. Kaziro (Tokyo University, Japan). The fusion vector, pGEX-3X, was obtained from Pharmacia LKB).

RNA extraction. Total RNA was extracted from left ventricle and right atrium using a modification of the acid guanidinium thiocyanatephenol-chloroform extraction method (28). Tissue samples were homogenized in $4.0 \mathrm{M}$ guanidinium buffer, extracted twice with acidic phenol-chloroform, and precipitated with isopropanol. The final pellet was washed with $70 \%$ ethanol, dissolved in diethylpyrocarbonate-treated water, and stored at $-80^{\circ} \mathrm{C}$. The integrity and purity of the RNA were assessed by gel electrophoresis and the ultraviolet absorbance ratio 
$(260 / 280 \mathrm{~nm})$; the sample was rejected if the ratio was $<1.6$ or if visual inspection of the gel photograph suggested degradation.

Construction of porcine riboprobes. cDNA was generated from total RNA isolated from porcine left ventricle through reverse transcription with oligo (dT) primers using in vitro transcriptase (Life Science Assoc., Bayport, NY). Partial fragments of porcine Gs $\alpha$, and Gi $\alpha_{2}$ clones then were obtained through amplification of porcine cardiac cDNA pools via PCR. To ensure specificity, sense and antisense primers (vide infra) were designed to amplify specific regions of these clones where the sequences are highly diversified among different genes in the family.

The primers for the Gs $\alpha$ probe spanned a 455-nucleotide segment (908-1362) within exons 12 and 13 of the porcine gene. The primers for the $\mathrm{Gi} \alpha_{2}$ probe spanned a 154-nucleotide segment (247-400) within exons 3 and 4 of the porcine gene. Amplified clones were sequenced and compared with known sequences of the Gs $\alpha$ and Gi $\alpha_{2}$ genes. The PCR primers for the Gs $\alpha$ gene included (1) 5'-AAATGGATCCAATGCTTCAATGAT-3' (sense) and (2) 5'-ACGTGAATTCCACAGCGCAGGTGAAGTGGC-3' (antisense). The PCR primers for the Gi $\alpha_{2}$ gene included (1) 5'-CTTCGAATTCTTGTCAAAGCCATGGGCAAC-3' (sense) (2) 5'-ATATGGATCCTGGTCAGCCCAGAGCCTCCG-3' (antisense).

PCR fragments were then subcloned into pGEM $3 Z$ or $4 Z$ plasmid DNA ( Promega, Madison, WI). Linearizing the plasmid constructs with proper restriction enzymes, we synthesized sense and antisense singlestrand RNA from Gs $\alpha$ and $\mathrm{Gi} \alpha_{2}$ clones using either Sp6 or T7 RNA polymerase. After synthesis, the riboprobes were gel purified to ensure that the full length of the riboprobe was used in the hybridization reaction. The antisense RNA was used as riboprobe and sense RNA as control RNA $(2-2,000 \mathrm{pg})$ in quantitative RNase protection assays.

RNase protection assay. In vitro transcription was performed to synthesize ${ }^{32} \mathrm{P}$-labeled riboprobes with specific activities ranging from $10^{8}$ to $5 \times 10^{8} \mathrm{cpm} / \mu \mathrm{g}$, using the gene constructs previously described. Total RNA $(20 \mu \mathrm{g})$ from tissue and various amounts of in vitro-synthesized sense-strand control RNA were hybridized with $2 \times 10^{4}$ to 8 $\times 10^{4} \mathrm{cpm}$ probe in $20 \mu \mathrm{l}$ of $80 \%$ formamide, $40 \mathrm{mM}$ Hepes ( $\mathrm{pH} 7.6$ ), $400 \mathrm{mM} \mathrm{NaCl}, 1.0 \mathrm{mM}$ EDTA for $12-16 \mathrm{~h}$ at $45^{\circ} \mathrm{C}$. Digestion buffer ( $300 \mu \mathrm{l}$ ), containing $300 \mathrm{mM} \mathrm{NaCl}, 10 \mathrm{mM}$ Tris- $\mathrm{HCl}, \mathrm{pH} 7.4,5 \mathrm{mM}$ EDTA, and $20 \mu \mathrm{g}$ of RNase A, and $3 \mathrm{U}$ of T1 RNase per $\mu \mathrm{g}$ of total RNA, was then added and incubated for $30 \mathrm{~min}$ at $37^{\circ} \mathrm{C}$. After treatment with proteinase $\mathrm{K}$ and extraction with phenol-chloroform, the RNaseresistant hybrids were precipitated and run on a $6 \%$ polyacrylamideurea gel. As a result of the high specificity of the riboprobes, only one band was present on gel autoradiography. The Gs $\alpha$ and Gi $\alpha_{2}$ mRNA signals were quantified by counting the excised gel band with a beta counter. After counting, the amount of control RNA could be expressed as $\mathrm{cpm} / \mu \mathrm{g}$ control RNA. These data were used to quantify mRNA levels in myocardial tissue ( $f m o l$ of specific RNA per mg of total RNA). The cardiac content of Gs $\alpha$ and Gi $\alpha_{2}$ mRNAs was calculated from the ratio of their signal to the signal from their sense-strand control RNA in the same hybridization reaction. A mammalian $18 \mathrm{~S}$ riboprobe $(400 \mathrm{cpm}$; plasmid construct from Ambion, Austin, TX) was used together with Gs $\alpha$ and $\mathrm{Gi} \alpha_{2}$ riboprobes in the hybridizations to assess the loading and hybridization conditions for each tissue sample. The high yield and very low specific activity of the $18 \mathrm{~S}$ riboprobe $\left(5 \times 10^{4}\right.$ to $8 \times 10^{4}$ $\mathrm{cpm} / \mu \mathrm{g}$; Megascript, Ambion ) was obtained to ensure accurate measurement of the $18 \mathrm{~S}$ transcript from $20 \mu \mathrm{g}$ of total RNA. RNase resistance was $<1 \%$, as checked by complete digestion of single-strand antisense riboprobe plus $40 \mu \mathrm{g}$ of transfer RNA (yeast) with RNase A and $\mathrm{T} 1$.

$\beta$-Adrenergic receptor kinase activity. $\beta$-Adrenergic receptor kinase enzymatic activity was determined using light-dependent phosphorylation of rhodopsin $(29,30)$. We purified rhodopsin from rod outer segments obtained from dark-adapted calf retina. Light-dependent phosphorylation of purified rhodopsin was first tested by using recombinant $\beta$-adrenergic receptor kinase (a gift from Dr. J. L. Benovic, Thomas Jefferson University, Philadelphia, PA ). $1 \mathrm{~g}$ of left ventricle was homogenized in $9 \mathrm{ml}$ of lysis buffer ( $50 \mathrm{mM}$ Tris- $\mathrm{HCl}, \mathrm{pH} 7.5,5 \mathrm{mM}$ EDTA, $10 \mu \mathrm{g} / \mathrm{ml}$ benzamidine, $20 \mu \mathrm{g} / \mathrm{ml}$ leupeptin, $40 \mu \mathrm{g} / \mathrm{ml} \mathrm{PMSF}$, and 5 $\mu \mathrm{g} / \mathrm{ml}$ pepstin A) and centrifuged at $45,000 \mathrm{~g}$ for $30 \mathrm{~min}$. The pellet was resuspended in $4 \mathrm{ml}$ of lysis buffer with $250 \mathrm{mM} \mathrm{NaCl}$ (used to dissociate membrane-associated $\beta$-adrenergic receptor kinase) and homogenized again in a power-driven glass rotor $\left(4^{\circ} \mathrm{C}\right)$. The pellet suspension was then recentrifuged, and ion exchange columns (Amicon) were used to remove $\mathrm{NaCl}$ from the supernatant of the pellet suspension. Both the supernatant and the supernatant of the pellet suspension then underwent DEAE-Sephacel column purification to eliminate endogenous kinases that could contaminate $\beta$-adrenergic receptor kinase-dependent phosphorylation. Both supernatant and pellet fractions were independently column purified.

$\beta$-Adrenergic receptor kinase-dependent phosphorylation was measured by incubating $100 \mu \mathrm{g}$ of protein from either fraction with $250 \mathrm{pmol}$ of rhodopsin in buffer containing $18 \mathrm{mM}$ Tris- $\mathrm{HCl}, 1.8 \mathrm{mM}$ EDTA, 4.8 $\mathrm{mM} \mathrm{MgCl} 2,73 \mu \mathrm{M} \mathrm{ATP}$, and $2.9 \mathrm{cpm} /$ fmol [ $\left.{ }^{32} \mathrm{P}\right] \mathrm{ATP}$. The $\beta$-adrenergic receptor kinase-dependent phosphorylation reaction was confirmed by adding protein kinase $\mathrm{A}$ inhibitor (Walsh inhibitor, $1 \mu \mathrm{M}$ ) and heparin $(10 \mu \mathrm{g} / \mathrm{ml})$ to the reaction. Heparin inhibited phosphorylation; protein kinase A inhibitor did not. Phosphorylation was light dependent. These experiments established that $\beta$-adrenergic receptor kinase was responsible for the phosphorylation. Protein concentrations for both pellet and supernatant were determined before and after DEAE-Sephacel purification, and the final enzyme activity was expressed as pmol of phosphate/min per $\mathrm{mg}$ of protein as well as per $\mathrm{g}$ of tissue. We have previously shown that $45,000-\mathrm{g}$ centrifugation $(30 \mathrm{~min}$ ) provides a supernatant that contains $<1 \%$ of the total cellular activity of p-nitrophenyl phosphatase (a sarcolemmal membrane-associated enzyme), suggesting excellent separation of cytosolic from membrane components (31).

Samples of right atrium were prepared as previously described, and $200 \mu \mathrm{g}$ of protein per sample was incubated with rhodopsin. There was insufficient right atrial tissue to determine soluble versus particulate compartmentation of $\beta$-adrenergic receptor kinase activity, so total activity was measured. Samples were electrophoresed on a $10 \%$-acrylamide gel that was stained with Coomassie blue and dried. Bands corresponding to rhodopsin were cut from the gel and counted in a scintillation counter.

Quantification of $\beta$-adrenergic receptor kinase, by immunoblotting. Assessment of left ventricular $\beta$-adrenergic receptor kinase, content was conducted using standard SDS-PAGE and immunoblotting techniques $(5,20)$. An antibody specific for $\beta$-adrenergic receptor kinase, and purified bovine $\beta$-adrenergic receptor kinase, were provided by Dr. J. L. Benovic. Transmural left ventricular samples were placed in a lysis buffer containing $20 \mathrm{mM}$ Tris- $\mathrm{HCl}$ ( $\mathrm{pH} 7.5$ ), $2 \mathrm{mM}$ EDTA, $10 \mu \mathrm{g} / \mathrm{ml}$ benzamidine, $10 \mu \mathrm{g} / \mathrm{ml}$ leupeptin, $100 \mu \mathrm{g} / \mathrm{ml} \mathrm{PMSF}$, and $5 \mu \mathrm{g} / \mathrm{ml} \mathrm{pep-}$ statin A. Samples were then homogenized using a Tekmar Tissuemizer (Tekmar Co., Cincinnati, $\mathrm{OH}$ ), and centrifuged, and resuspended by sonication in lysis buffer. $80 \mu \mathrm{g}$ of protein from each left ventricular sample was mixed with Laemmli buffer, boiled, and electrophoresed on a $10 \%$ denaturing gel. Proteins were transferred to polyvinylidene difluoride paper (Immobolin-P; Millipore Corp., Milford, MA); transfer efficiency was determined by Ponceau staining. The membrane was blocked for $2 \mathrm{~h}$ in TBS containing $0.1 \%$ Tween 20 and 5\% nonfat dry milk and developed by conventional methods using anti- $\beta$-adrenergic receptor kinase ${ }_{1}$ antiserum followed by exposure to horseradish peroxidase-lined anti-rabbit immunoglobulin (1:1,000 in TBS). The blots were developed by the enhanced chemiluminescence method, and bands were visualized after exposing blots to $\mathrm{x}$-ray film. Densities of bands comigrating with purified bovine $\beta$-adrenergic receptor kinase, were quantified by densitometric scanning.

Statistics. Data are expressed as mean \pm 1 SD. Specific measurements were compared using Student's $t$ test for paired (heart rate responses before and after bisoprolol treatment) or unpaired data (all other comparisons). The null hypothesis was rejected when $P<0.05$ (two-tailed unless otherwise stated).

\section{Results}

Heart rate. Heart rate after cholinergic receptor blockade with glyocopyrrolate, a long-acting muscarinic cholinergic antago- 

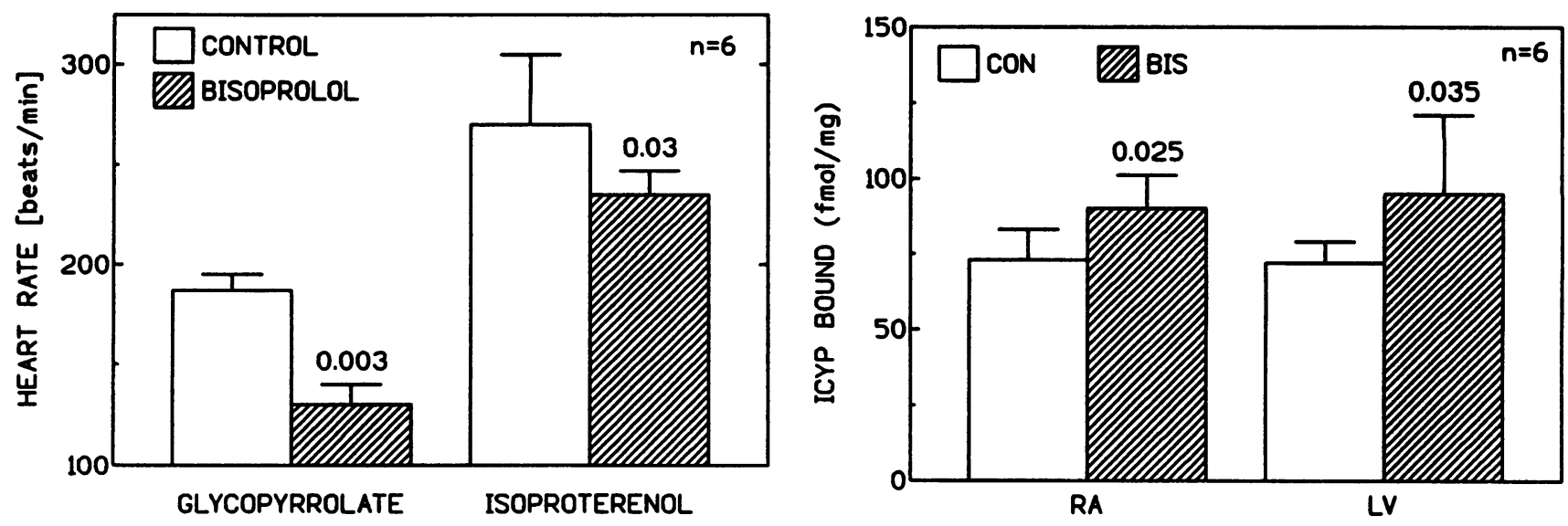

Figure 1. (Left panel) Heart rate responses before and after $3 \mathrm{wk}$ of bisoprolol treatment. The heart rate response to glycopyrrolate, a muscarinic cholinergic receptor antagonist, was decreased after bisoprolol treatment. The maximal heart rate response to isoproterenol was also decreased. Open bars represent mean values from control animals; cross-hatched bars represent mean values from animals treated with bisoprolol; error bars denote 1 SD. Numbers above bars denote $P$ values (paired, one-tailed). $n=6$, both groups. (Right panel) Results of saturation isotherms performed on myocardial homogenates. After bisoprolol treatment, $\beta$-adrenergic receptor number was increased in the right atrium $(R A)$ and left ventricle $(L V)$. Data are expressed as ICYP bound in fmol/mg protein. Open bars represent mean values from control (CON) animals; cross-hatched bars represent mean values from animals treated with bisoprolol $(B I S)$; error bars denote $1 \mathrm{SD}$. Numbers above bars denote $P$ values (unpaired, onetailed). $n=6$, both groups.

nist, was decreased after bisoprolol treatment (control: $187 \pm 8$ bpm; bisoprolol: $130 \pm 10 \mathrm{bpm} ; P<0.003$ ). Maximal isoproterenol-stimulated heart rate was also decreased (control: $270 \pm 35$ bpm; bisoprolol: $235 \pm 12 \mathrm{bpm} ; P=0.03$ ). These data suggest that the animals were receiving an adequate amount of bisoprolol to obtain an inhibiting effect upon heart rate (Fig. 1, left panel).

$\beta$-Adrenergic receptor binding studies. Fig. 1 (right panel) shows the results of saturation binding isotherm experiments. Bisoprolol treatment was associated with upregulation of $\beta$ adrenergic receptor in the right atrium (control: $73 \pm 10 \mathrm{fmol} /$ mg; bisoprolol: $90 \pm 11 \mathrm{fmol} / \mathrm{mg} ; P=0.025$ ) and in the left ventricle (control: $72 \pm 7 \mathrm{fmol} / \mathrm{mg}$; bisoprolol: $95 \pm 26 \mathrm{fmol} / \mathrm{mg}$; $P=0.035$ ). Data from the left ventricle represent mean values of two saturation isotherms per tissue per animal $(n=6)$. Data from the right atrium represent a single experiment (triplicate points; eight concentrations of ICYP) from each animal ( $n$ $=6$ ). Bisoprolol treatment did not affect the $K_{\mathrm{d}}$ for ICYP in either the right atrium (control: $150 \pm 25 \mathrm{pM}$; bisoprolol: $167 \pm 20 ; P=\mathrm{NS}$ ) or the left ventricle (control: $85 \pm 23 \mathrm{pM}$; bisoprolol: $97 \pm 16 \mathrm{pM} ; P=\mathrm{NS}$ ). Mean $r^{2}$ values for the Scatchard analyses were 0.98 . In left ventricular samples, competitive binding studies showed upregulation among both $\beta_{1}$-adrenergic receptors (control: $51 \pm 6 \mathrm{fmol} / \mathrm{mg}$; bisoprolol: $67 \pm 13 \mathrm{fmol} / \mathrm{mg}$; $P=0.02$ ) and $\beta_{2}$-adrenergic receptors (control: $21 \pm 3 \mathrm{fmol} /$ mg; bisoprolol: $28 \pm 6 \mathrm{fmol} / \mathrm{mg} ; P<0.03)$. The $K_{\mathrm{i}}$ for the antagonist was unchanged in either $\beta_{1}$-adrenergic receptors (control: $1 \pm 1 \mu \mathrm{M}$; bisoprolol: $2 \pm 3 \mu \mathrm{M}$ ) or $\beta_{2}$-adrenergic receptors (control: $7 \pm 8 \mathrm{nM}$; bisoprolol: $15 \pm 14 \mathrm{nM}$ ).

Adenylylcyclase activity. Gs-dependent ( GTP $\gamma \mathrm{S})$ and catalyst-dependent (forskolin) stimulation of cAMP production were unchanged in the right atrium and left ventricle by bisoprolol treatment (Table I). However, $\beta$-adrenergic receptor-dependent stimulation of cAMP was increased twofold in left ventricular membranes from bisoprolol-treated animals ( $P$ $<0.0001$ ). Basal values were similar in both chambers from both groups. Thus, $\beta$-adrenergic receptor stimulation resulted in a substantial increase in net cAMP production in left ventricular membranes from bisoprolol-treated animals.

Quantification of Gi $\alpha_{2}$ and Gs $\alpha$ by immunoblotting. To determine whether a chronic reduction in myocardial $\beta$-adrenergic receptor activation was associated with altered levels of cardiac Gs $\alpha$ and $\operatorname{Gi} \alpha_{2}$, quantitative immunoblotting was performed. Quantitative immunoblotting using purified antibodies against Gs $\alpha$ showed reduced amounts of Gs $\alpha$ in membranes from the bisoprolol-treated animals in both the right atrium and the left ventricle (Fig. 2; Tables II and III). The reduction was 39\% in the right atrium $(P<0.12)$ and $55 \%$ in the left ventricle $(P=0.01)$. Quantitative immunoblotting, performed using a purified antibody specific for $\mathrm{Gi} \alpha_{2}$, showed reduced amounts of $\mathrm{Gi} \alpha_{2}$ in membranes from the bisoprolol-treated animals in both the right atrium and the left ventricle (Fig. 2; Tables II and III). The reduction was $42 \%$ in the right atrium $(P<0.005)$ and $59 \%$ in the left ventricle $(P=0.0002)$.

Quantification of $\mathrm{Gi \alpha}_{2}$ and $\mathrm{Gs} \alpha \mathrm{mRNA}$. The content of both

Table I. Adenylyl Cyclase Activity after Bisoprolol Treatment

\begin{tabular}{lccccccc}
\hline & \multicolumn{3}{c}{ Right atrium } & & \multicolumn{3}{c}{ Left ventricle } \\
\cline { 2 - 3 } \cline { 7 - 8 } & Con & Bis & $P$ & & Con & Bis & $P$ \\
\hline Basal & $22 \pm 5$ & $26 \pm 5$ & NS & $29 \pm 5$ & $33 \pm 6$ & NS \\
Iso + GTP & $40 \pm 7$ & $47 \pm 12$ & NS & $56 \pm 5$ & $113 \pm 10$ & 0.0001 \\
GTP $\gamma$ S & $169 \pm 15$ & $171 \pm 9$ & NS & & $224 \pm 24$ & $222 \pm 46$ & NS \\
AlF & $139 \pm 21$ & $136 \pm 21$ & NS & & $267 \pm 32$ & $263 \pm 42$ & NS \\
Forsk & $289 \pm 53$ & $208 \pm 94$ & NS & $349 \pm 57$ & $357 \pm 46$ & NS
\end{tabular}

Data represent cAMP produced in $\mathrm{pmol} / \mathrm{mg}$ per $\min \pm 1 \mathrm{SD}$ and are net values (basal subtracted). $P$, control versus bisoprolol (unpaired, twotailed $t$ test). $n=6$ for each group. Iso, $10 \mu \mathrm{M}$ isoproterenol; GTP, 100 $\mu \mathrm{M}$ guanosine 5'-triphosphate; GTP $\gamma \mathrm{S}, 100 \mu \mathrm{M}$ guanosine 5'-O-(3thiotriphosphate); AlF, $100 \mu \mathrm{M}$ aluminum fluoride; Forsk, $100 \mu \mathrm{M}$ forskolin. 

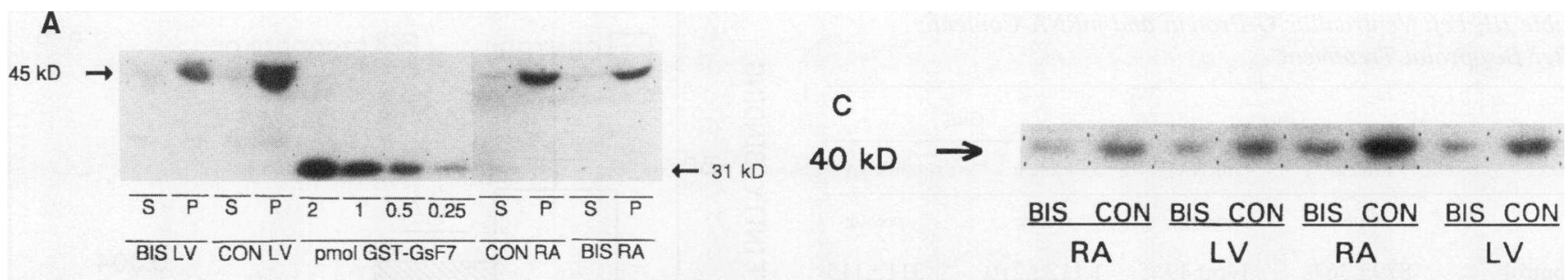

B
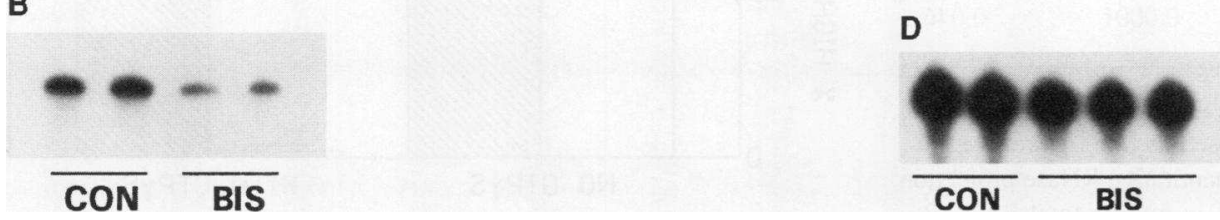

Figure 2. The effects of chronic bisoprolol treatment on myocardial Gs $\alpha$ and Gi $\alpha_{2}$ protein and mRNA content $(A$ and $B)$. ( $A$ ) The photograph is an autoradiogram of an immunoblot using purified antibodies specific for Gs $\alpha$ in crude membrane homogenates of right atrial (RA) and left ventricular $(L V)$ samples from a bisoprolol-treated $(B I S)$ and a control $(C O N)$ animal. $100 \mu \mathrm{g}$ of protein from the soluble $(S)$ and membranebound $(P)$ fractions was examined for each preparation to evaluate labile G-protein activity. This autoradiogram indicates that myocardium from the bisoprolol-treated animal had a lower Gs $\alpha$ content than that from the control animal in both fractions in both chambers. Data from all 12 animals are summarized in Tables II and III. Lanes 5-8 show an immunoblot using the same purified antibodies specific for Gs $\alpha$ against varied concentrations of purified fusion protein (GST-GsF7) for quantitative immunoblotting. These findings indicate that a linear relation exists between protein applied and signal obtained. $(B)$ The photograph displays quantitative RNase protection assays using a porcine Gs $\alpha$ riboprobe. Reduced mRNA levels for Gs $\alpha$ was found in the left ventricle $(L V)$ from animals after bisoprolol treatment (BIS) compared with controls (CON). The photograph displays data from two animals in each group. Data from all 12 animals are summarized in Table III $(C$ and $D)$. $(C)$ The photograph is an autoradiogram of an immunoblot using purified antibodies specific for Gi $\alpha_{2}$ in crude membrane homogenates of right atrial $(R A)$ and left ventricular $(L V)$ samples from two bisoprolol-treated $(B I S)$ and two control $(C O N)$ animals. $100 \mu \mathrm{g}$ of protein from membrane-bound fractions was examined to evaluate G-protein activity. This autoradiogram indicates that myocardium from bisoprolol-treated animals had a lower Gi $\alpha_{2}$ content than that from control animals in both chambers. Data from all 12 animals are summarized in Tables II and III. (D)The photograph displays quantitative RNase protection assays using a porcine Gi $\alpha_{2}$ riboprobe. Reduced mRNA levels for Gi $\alpha_{2}$ were found in the left ventricle ( $\left.L V\right)$ from animals after bisoprolol treatment (BIS) compared with controls (CON). The photograph displays data from two control and three bisoprololtreated animals. Data from all 12 animals are summarized in Table III.

G-proteins was reduced in the right atrium and left ventricle after chronic reduction in $\beta$-adrenergic receptor activation. Furthermore, RNase protection assays showed that the mRNA content for both G-proteins was reduced in the left ventricle (Fig. 2; Table III). Gs $\alpha$ mRNA content was reduced by $44 \%$ ( $P$ $=0.01)$, and Gi $\alpha_{2}$ mRNA content was reduced by $30 \%$ ( $P$ $=0.048$ ).

$\beta$-Adrenergic receptor agonist affinity. In left ventricular membranes, the proportion of $\beta$-adrenergic receptors showing high affinity binding for (-)-isoproterenol was unchanged by bisoprolol treatment (control: $46 \pm 12 \%$; bisoprolol: $34 \pm 13 \%$; $P=$ NS; Figs. 3 and 4 ). In the absence of added guanine nucleotides, receptors displaying high affinity binding had a

Table II. Right Atrial G-Protein Content after Bisoprolol Treatment

\begin{tabular}{lcc}
\hline & Gs $\alpha$ & Gi $\alpha_{2}$ \\
\hline & pmolg & pmolg \\
Control & $683 \pm 250$ & $1,312 \pm 157$ \\
Bisoprolol & $414 \pm 293$ & $759 \pm 342$ \\
$P$ & 0.12 & 0.005 \\
\hline
\end{tabular}

Values represent mean $\pm 1 \mathrm{SD}$. G-protein levels were determined by quantitative immunoblotting and are expressed as pmol/g wet weight tissue. $P$ values: control versus bisoprolol (unpaired, two-tailed). $n=6$ for each group. similar $K_{\mathrm{i}}$ for isoproterenol (control: $9 \pm 6 \mathrm{nM}$; bisoprolol: $10 \pm 14 \mathrm{nM}$ ), and receptors displaying low affinity binding for isoproterenol also had a similar $K_{\mathrm{i}}$ (control: $0.8 \pm 0.7 \mu \mathrm{M}$; bisoprolol: $0.8 \pm 0.6 \mu \mathrm{M}$ ). However, a difference in affinity state was observed in the presence of nonhydrolyzable GTP analogs (Fig. 3). Left ventricular membranes from control animals showed the expected shift to low affinity agonist binding when either Gpp [NH]p (data not shown) or GTP $\gamma \mathrm{S}$ was added, but left ventricular membranes from bisoprolol-treated animals were resistant to uncoupling (Figs. 3 and 4). Thus, after bisoprolol treatment, the majority of $\beta$-adrenergic receptors showing high affinity agonist binding in the absence of GTP analogs continued to show high affinity agonist binding when GTP ana-

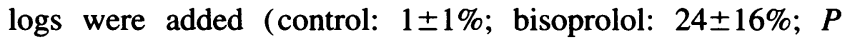
$<0.004$; Figs. 3 and 4 ).

Quantification of $\beta$-adrenergic receptor kinase activity. To examine the activity of $\beta$-adrenergic receptor kinase, we used a modification of previously described methods $(29,30)$, in which the phosphorylation of rhodopsin, a reaction that requires $\beta$-adrenergic receptor kinase, is used. The phosphorylation is dependent upon light (Fig. 5) and is inhibited by heparin, a $\beta$-adrenergic receptor kinase inhibitor (data not shown). The modification we have used allows for determination of $\beta$-adrenergic receptor kinase activity in both the soluble and particulate fractions of membrane homogenates (30). Previous reports (17, 21 ) have not measured particulate $\beta$-adrenergic receptor kinase activity. In the present study chronic reduction in $\beta$-adrenergic receptor activation was associated with reduction in $\beta$-adrenergic receptor kinase activity in both soluble and particulate frac- 
Table III. Left Ventricular G-Protein and mRNA Content after Bisoprolol Treatment

\begin{tabular}{lccccc}
\hline & \multicolumn{2}{c}{ Gs $\alpha$} & & \multicolumn{2}{c}{ Gi $\alpha_{2}$} \\
\cline { 2 - 3 } \cline { 5 - 6 } \cline { 5 - 6 } & Protein & mRNA & & Protein & mRNA \\
\hline Control & $879 \pm 367$ & $146 \pm 49$ & & $1,112 \pm 210$ & $311 \pm 115$ \\
Bisoprolol & $396 \pm 190$ & $81 \pm 27$ & & $452 \pm 69$ & $217 \pm 44$ \\
$P$ & 0.02 & 0.01 & & 0.0001 & 0.046
\end{tabular}

Values represent mean $\pm 1 \mathrm{SD}$. G-protein levels were determined by quantitative immunoblotting and are expressed as pmol/g wet weight tissue. mRNA levels were determined by quantitative RNase protection assays and are expressed as specific mRNA in pmol/g total RNA. $P$ values: control versus bisoprolol (unpaired; protein, two-tailed; mRNA, one-tailed). $n=6$ for each group.

tions of left ventricular homogenates (Fig. 5; Table IV). Soluble fraction $\beta$-adrenergic receptor kinase activity was reduced by 25\% $(P<0.01)$, and membrane-associated $\beta$-adrenergic receptor kinase activity was reduced by $38 \%(P<0.01)$. Expressed as total $\beta$-adrenergic receptor kinase activity per wet weight left ventricle, the reduction in $\beta$-adrenergic receptor kinase activity was $30 \%(P<0.04)$.

In addition, total $\beta$-adrenergic receptor kinase activity was assessed in right atrial samples from four control and four bisoprolol-treated animals. These experiments indicated that total $\beta$ adrenergic receptor kinase activity was unaltered in right atrial samples (control: $26 \pm 10 \mathrm{fmol} / \mathrm{mg}$ per $\mathrm{min}$; bisoprolol: $28 \pm 10$ $\mathrm{fmol} / \mathrm{mg}$ per $\min ; P=0.8$ ). Thus, reduced $\beta$-adrenergic receptor kinase activity associated with reduced $\beta$-adrenergic receptor activation is found only in the left ventricle, not in the right atrium.

Quantification of $\beta$-adrenergic receptor kinase, by immunoblotting. To determine whether a chronic reduction in myocardial $\beta$-adrenergic receptor activation was associated with altered levels of $\beta$-adrenergic receptor kinase ${ }_{1}$ protein content,

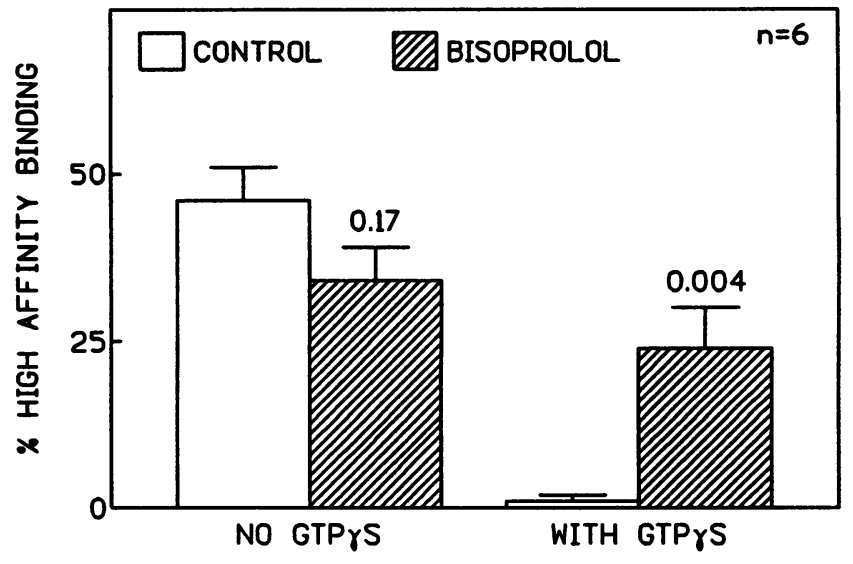

Figure 4. Competitive binding assays, performed to assess the proportion of left ventricular $\beta$-adrenergic receptors displaying high and low affinity binding for $(-)$-isoproterenol. Left ventricular membranes from control and bisoprolol-treated animals displayed similar proportions of receptors showing high affinity binding in the absence of GTP $\gamma \mathrm{S}$, but left ventricular membranes from bisoprolol-treated animals were resistant to uncoupling with GTP $\gamma$ S. Bars represent mean values; error bars represent 1 SEM. Numbers above bars denote $P$ values (unpaired, twotailed). $n=6$ for both groups

immunoblotting was performed. Immunoblotting using a purified antibody against $\beta$-adrenergic receptor kinase ${ }_{1}$ showed no change in immunologically detected $\beta$-adrenergic receptor kinase $_{1}$ protein content in left ventricular samples from animals treated with bisoprolol (control: $0.45 \pm 0.21$ arbitrary densitometry units; bisoprolol: $0.45 \pm 0.13$ arbitrary densitometry units; $n$ $=6$ both groups; $P=1.0$ ). Right atrial $\beta$-adrenergic receptor kinase $_{1}$ content was not assessed (insufficient material).

\section{Discussion}

To determine whether $\beta$-adrenergic receptor agonist activation influences $\mathrm{G}$-protein expression and $\beta$-adrenergic receptor ki-
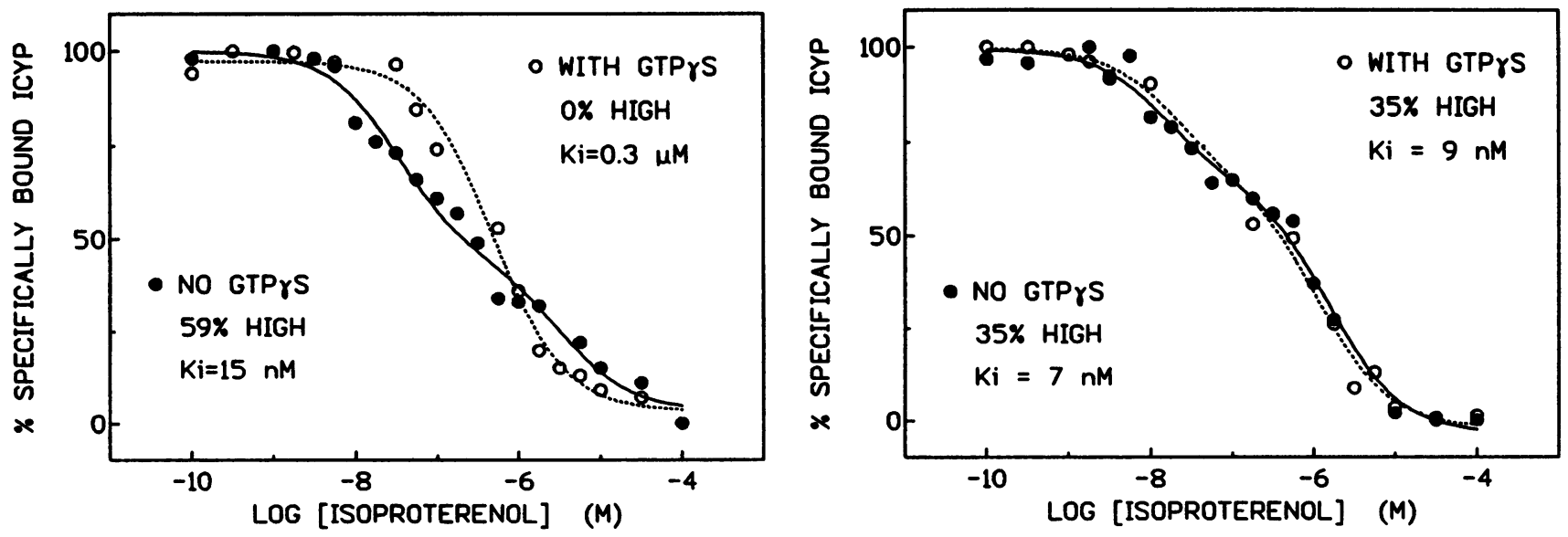

Figure 3. Competitive binding assays, performed to assess the proportion of left ventricular $\beta$-adrenergic receptors displaying high and low affinity binding for (-)-isoproterenol. (Left panel) Left ventricular membranes from a control animal; 59\% of the receptors displayed high affinity binding, and all of these were converted to low affinity binding with the addition of GTP $\gamma$ S. (Right panel) Left ventricular membranes from a bisoprololtreated animal; $35 \%$ of the receptors displayed high affinity binding, and these were resistant to uncoupling with GTP $\gamma \mathrm{S}$. Data from six control and six bisoprolol-treated animals are shown in Fig. 4. 


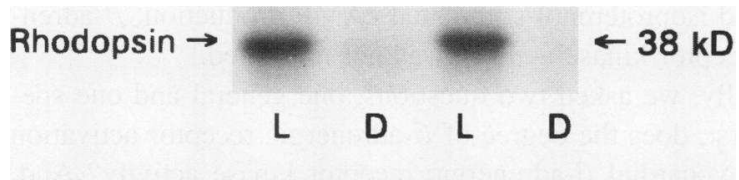

LV BARK ACTIVITY

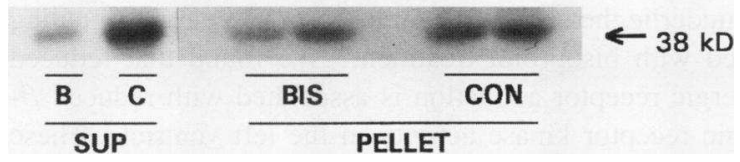

Figure 5. Assessment of $\beta$-adrenergic receptor kinase ( $\beta A R K$ ) activity in left ventricular membranes. (Top) Left ventricular membranes from a control animal showed that the phosphorylation of rhodopsin was light dependent, as expected for $\beta$-adrenergic receptor kinase. The phosphorylation reaction was inhibited with heparin, a $\beta$-adrenergic receptor kinase inhibitor (data not shown). (Bottom) Left ventricular membranes from bisoprolol-treated ( $B$ or $B I S)$ and control $(C$ or $C O N)$ animals. Bisoprolol treatment $(0.2 \mathrm{mg} / \mathrm{kg}$ per $\mathrm{d}, 35 \mathrm{~d})$ was associated with reduced $\beta$-adrenergic receptor kinase activity in the soluble component (supernatant; SUP) as well as in the particulate component (PELLET). Soluble components are shown for a single animal from each group; particulate fractions are shown for two animals from each group. Data from 10 animals are shown in Table IV.

nase activity, we examined the effects of chronic $\beta$-adrenergic receptor antagonist treatment on components of the myocardial $\beta$-adrenergic receptor-G-protein-adenylyl cyclase pathway in porcine myocardium. We have found three new alterations in cardiac adrenergic signaling associated with chronic reduction in $\beta$-adrenergic receptor agonist activation. First, there is coordinate downregulation of $\mathrm{Gi} \alpha_{2}$ and $\mathrm{Gs} \alpha$ mRNA and protein expression in the left ventricle; reduced G-protein content was also found in the right atrium. Second, after chronic reduction in $\beta$-adrenergic receptor activation, there is a twofold increase in $\beta$-adrenergic receptor-dependent stimulation of adenylyl cyclase and a persistent high affinity state of the $\beta$-adrenergic receptor in left ventricular membranes. Finally, there is a reduction in left ventricular $\beta$-adrenergic receptor kinase activity.

Downregulation of $G$-proteins. In the left ventricle, mRNA content for both $\mathrm{Gi} \alpha_{2}$ and $\mathrm{Gs} \alpha$ was significantly decreased in treated pigs, to a degree that reflected reductions in protein expression. Thus, chronic reduction in $\beta$-adrenergic receptor activation is associated with coordinate decreases in mRNA and protein expression for Gs $\alpha$ and $\mathrm{Gi} \alpha_{2}$ in the left ventricle. Decreased $\mathrm{Gi} \alpha_{2}$ and Gs $\alpha$ protein and mRNA content in the left ventricle following chronic reduction of $\beta$-adrenergic receptor activation suggests that transcriptional regulation (or mRNA stability) may be an important determinant of G-protein expression and that such regulation may be linked to $\beta$-adrenergic receptor activation.

A recent study exploring the effects of sustained adrenergic activation on $\mathrm{Gi} \alpha_{2}$ found that isoproterenol infusion increased cardiac $\mathrm{Gi} \alpha_{2}$ protein content and transcription rates of $\mathrm{Gi} \alpha_{2}$ mRNA; message stability was unchanged (11). It is noteworthy that the $\mathrm{Gi} \alpha_{2}$ gene contains a putative cAMP response element (32). These data, taken together, suggest that Gi $\alpha_{2}$ protein expression may be altered in a manner that reflects adrenergic activation. Thus, in the setting of sustained adrenergic activation, with its attendant increase in cAMP levels, gene transcription and thus protein expression are increased. One might speculate that, in settings of reduced adrenergic activation ( $\beta$-adrener- gic receptor antagonist treatment), reduced basal cAMP levels might have the reverse effect. Gi $\alpha_{2}$ gene transcription and thus protein expression would be expected to decrease. Our data support this idea, since protein expression and Gi $\alpha_{2}$ mRNA levels were both decreased, in association with chronic reduction in $\beta$-adrenergic receptor activation. Although $\beta$-adrenergic receptor-mediated cAMP production was increased in vitro, the heart rate response was diminished. This apparent paradox may reflect the continued presence of bisoprolol in vivo but not in vitro. Our speculation that reduced cAMP may be linked to $\mathrm{Gi} \alpha_{2}$ gene transcription implies that bisoprolol reduced $\beta$ adrenergic receptor-mediated cAMP in vivo.

We have previously reported reduced cardiac Gi $\alpha_{2}$ mRNA and protein content in a porcine model of heart failure $(5,18$, 19). Thus, chronic reduction in $\beta$-adrenergic receptor activation (bisoprolol treatment) and heart failure have similar effects upon $\mathrm{Gi} \alpha_{2}$ expression in the porcine heart. It is noteworthy that although heart failure is associated with increased levels of plasma norepinephrine, all measures of adenylyl cyclase are reduced, including reduced basal cAMP production (5). A possible explanation for reduced $\mathrm{Gi} \alpha_{2}$ expression in these two rather diverse settings is that both would be expected to have reduced cAMP response element activation and therefore reduced $\mathrm{Gi}_{2}$ gene transcription. It should be kept in mind, however, that human heart failure appears to be associated with increased $\mathrm{Gi} \alpha_{2}$ expression $(7,8)$; so the effects of heart failure on $\mathrm{Gi}$ expression may be model or species specific.

The Gs $\alpha$ gene lacks a cAMP response element (33); so in contrast to $\mathrm{Gi} \alpha_{2}$, a mechanism linking $\beta$-adrenergic receptor activation and Gs mRNA expression has not been established. Any potential link may not be direct since we have found similar reductions in Gs $\alpha$ mRNA and protein expression in porcine left ventricle in both heart failure (5) (sustained adrenergic activation) and $\beta$-adrenergic receptor antagonist treatment (attenuated adrenergic activation ). It is difficult to advance a unifying hypothesis that encompasses these data while proposing adrenergic activation as the pivotal factor linking receptor activation with Gs $\alpha$ expression. The similarities between heart failure and $\beta$-adrenergic receptor blockade with respect to Gs $\alpha$ expression are intriguing. The precise mechanisms that result in reduced Gs $\alpha$ mRNA in the setting of reduced $\beta$-adrenergic receptor activation remain to be established. Based upon quantitative measures of mRNA content, we propose that pretranslational regulation of Gs $\alpha$ may provide a means to offset altered signal transduction induced by agents that inhibit agonist-receptor interactions in the heart.

There have been very few previous studies examining the effects of chronic $\beta$-adrenergic receptor antagonist treatment on cardiac G-protein expression, and none have used quantitative immunoblotting or RNase protection assays. Previous data come mostly from studies conducted on right atrial biopsies obtained from patients undergoing cardiac surgery (1). In general, these studies report no change in measures of G-protein expression. Differences between these prior studies and the present study may reflect the difficulty in obtaining true control tissue in the human studies, differences in species, and differences in the techniques used to measure G-protein expression.

Alterations in adenylylcyclase activity after $\beta$-adrenergic receptor antagonist treatment have been reported by others (1). For example, a recent study (34) showed that propranolol, a nonselective $\beta$-adrenergic receptor antagonist, resulted in increased net isoproterenol-stimulated cAMP production in ca- 
Table IV. Left Ventricular $\beta$-Adrenergic Receptor Kinase Activity

\begin{tabular}{lcrl}
\hline & Control & Bisoprolol & $P$ \\
\hline Cytosol & $23 \pm 4$ & $17 \pm 4$ & 0.45 \\
Membrane & $15 \pm 2$ & $9 \pm 2$ & 0.002 \\
Total & $37 \pm 7$ & $26 \pm 4$ & 0.02 \\
$\%$ in cytosol & $60 \pm 4$ & $64 \pm 4$ & 0.15 \\
\hline
\end{tabular}

Values are mean $\pm 1 \mathrm{SD}$ and represent ${ }^{32} \mathrm{P}$ incorporated ( $\mathrm{fmol} / \mathrm{mg}$ per $\min$ ). $n=5$ in both groups. $P$ values: control versus bisoprolol (unpaired, two-tailed). $n=5$ for each group.

nine left ventricular myocardium after $7 \mathrm{~d}$ of treatment. These data are consistent with our findings with respect to adenylyl cyclase activity; however, no G-protein quantification was performed in that study. Chronic $\beta$-adrenergic receptor blockade may affect inhibitory as well as excitatory receptors. For example, it was recently shown that metoprolol administration for $10 \mathrm{~d}$ resulted in reduced numbers of muscarinic cholinergic $\left(M_{2}\right)$ receptors in rat heart and lung and reduced adenosine $A_{1}$ receptors in rat brain (35). These data suggest that chronic reduction in $\beta$-adrenergic activation can affect multiple receptor pathways in multiple organs.

$\beta$-Adrenergic receptor kinase activity. The alterations in G-protein expression associated with chronic reduction in $\beta$ adrenergic receptor activation fail to provide a compelling reason why adenylyl cyclase activity shows a receptor-dependent doubling of cAMP production. Previous studies have indicated a specific effect on adenylyl cyclase activity similar to the one we describe in response to chronic $\beta$-adrenergic receptor antagonist treatment $(1,34)$. Potential mechanisms underlying this alteration in adrenergic signaling include alterations in receptor number, in receptor-agonist affinity, or in receptor-Gs $\alpha$ coupling.

An increase in $\beta$-adrenergic receptor number may have contributed to increased $\beta$-adrenergic receptor-mediated cAMP production, but since receptor number increased $32 \%$ and cAMP production increased $100 \%$, additional factors may be important. The affinity of the $\beta$-adrenergic receptor for (-)-isoproterenol was not altered by bisoprolol treatment since the affinity constants for the high and low affinity states of the receptors were not altered. Furthermore, the proportion of receptors showing high affinity binding with (-)-isoproterenol was similar in control and bisoprolol-treated animals. The notable difference associated with bisoprolol treatment was the inability of nonhydrolyzable GTP analogs to uncouple the receptors from Gs $\alpha$. Thus, after bisoprolol treatment a substantial residual number of the receptors exhibited persistent high affinity for (-)-isoproterenol. Based on the idea that stabilization of high affinity binding correlates with agonist response, this alteration would be expected to result in more efficient $\beta$-adrenergic receptor-mediated signal transduction and may play a mechanistic role in the observed increase in $\beta$-adrenergic receptor-dependent cAMP production. The relative inefficacy of GTP analogs to promote receptor-Gs uncoupling (the phenomenon of persistent high affinity agonist binding) has also been reported to occur in myocardial $\beta$-adrenergic receptors in hibernating mammals (36). The study by Morris et al. (36), like ours, found that persistent high affinity binding was associated with increased isoproterenol-stimulated cAMP production; $\beta$-adrenergic receptor kinase activity was not measured.

Finally, we asked two questions, one general and one specific. First, does the degree of $\beta$-adrenergic receptor activation affect myocardial $\beta$-adrenergic receptor kinase activity? And, more specifically, does reduced $\beta$-adrenergic receptor kinase activity underlie the observed alterations in adrenergic signaling associated with bisoprolol treatment? We found that reduced $\beta$-adrenergic receptor activation is associated with reduced $\beta$ adrenergic receptor kinase activity in the left ventricle. These data are particularly interesting in the context of recent reports showing that sustained $\beta$-adrenergic receptor activation (human heart failure) is associated with increased left ventricular $\beta$ adrenergic receptor kinase activity $(17,21)$. We have recently reported that left ventricular $\beta$-adrenergic receptor kinase activity is also increased in a porcine model of heart failure (37). Taken together, data from these prior studies and our present study suggest that there is an inverse relation between adrenergic receptor activation and $\beta$-adrenergic receptor kinase activity in the left ventricle. It is noteworthy that bisoprolol treatment was associated with increased isoproterenol-stimulated cAMP production in left ventricular but not right atrial myocardium. If altered $\beta$-adrenergic receptor kinase activity is an important factor in the mechanism for enhanced adrenergic signaling, one would expect altered levels of $\beta$-adrenergic receptor kinase in the left ventricle but not the right atrium. This is precisely what we found.

Although we found reduced enzymatic activity of the $\beta$ adrenergic receptor kinase, we found no change in immunologi-

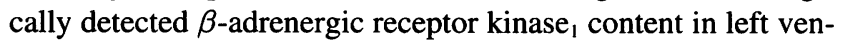
tricular myocardium. There are several isoforms of G-proteincoupled receptor kinases, all potentially capable of promoting phosphorylation of rhodopsin (38). The present data do not identify the specific G-protein-coupled receptor kinase that accounts for reduced activity. Our immunoblotting data suggest that $\beta$-adrenergic receptor kinase ${ }_{1}$ content is not altered by bisoprolol treatment. G-protein receptor kinase ${ }_{5}$ mRNA is expressed abundantly in mammalian heart (38). It is possible that reduced expression of G-protein-coupled receptor kinase ${ }_{5}$ may contribute to the findings of the present study. This hypothesis cannot be tested until an antibody against G-protein receptor kinase ${ }_{5}$ (or a specific enzymatic assay) becomes available to measure G-protein-coupled receptor kinase ${ }_{5}$ protein content or activity. An alternative explanation is that the $\beta$-adrenergic receptor kinase $_{1}$ protein, although unchanged in amount, is functionally altered. The current data strongly support the hypothesis that left ventricular $\beta$-adrenergic receptor kinase activity is influenced by the degree of $\beta$-adrenergic receptor activation and that $\beta$-adrenergic receptor activity affects adrenergic signaling in the heart.

$\beta$-Adrenergic receptor kinase has been shown to phosphorylate only the $\beta_{2}$-adrenergic receptor (39). Whether the $\beta_{1^{-}}$ adrenergic receptor is phosphorylated by $\beta$-adrenergic receptor kinase in vivo is unknown. In the present study we found a significant increase in $\beta_{2}$-adrenergic receptor number, and other data indicate that $\beta_{2}$-adrenergic receptors may be more tightly coupled to adenylylcyclase than are $\beta_{1}$-adrenergic receptors (1). Therefore, alterations in $\beta$-adrenergic receptor kinase activity are likely to be relevant in the present study. Our demonstration that CAMP production is increased only in the chamber where $\beta$-adrenergic receptor kinase activity is reduced under- 
scores the potential biological importance of $\beta$-adrenergic receptor kinase activity in adrenergic signaling in vivo.

The precise mechanism by which alteration in $\beta$-adrenergic receptor activation may influence $\beta$-adrenergic receptor kinase protein expression is unknown. The $\beta$-adrenergic receptor kinase $_{1}$ gene sequence was recently published (40) and does not appear to contain a typical cAMP response element. However, the absence of a typical cAMP response element does not exclude the possibility that cAMP levels may influence $\beta$-adrener-

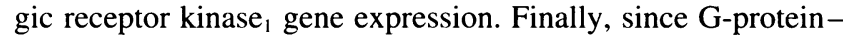
coupled receptor kinase ${ }_{5}$ may contribute to the findings of the present study, it will be of interest to see whether the G-proteincoupled receptor kinase $_{5}$ gene contains cAMP response elements.

The association of persistent high affinity agonist binding (persistent $\beta$-adrenergic receptor-Gs coupling) with reduced $\beta$-adrenergic receptor kinase activity, an enzyme known to phosphorylate and thereby uncouple the $\beta$-adrenergic receptor from Gs, suggests that reduced $\beta$-adrenergic receptor kinase activity may play a role to enhance $\beta$-adrenergic receptormediated cAMP production after chronic reduction in $\beta$-adrenergic receptor activation. This implies that $\beta$-adrenergic receptor phosphorylation is a prerequisite for the GTP-induced rightward displacement of the isoproterenol competition curve.

In conclusion, we have shown that chronic reduction in myocardial $\beta$-adrenergic receptor activation (bisoprolol treatment) is associated with alterations in adrenergic signaling. Expression of cardiac G-proteins is reduced at the mRNA and protein levels. There is a striking increase in $\beta$-adrenergic receptor-mediated cAMP production in association with persistent high affinity agonist binding. Myocardial $\beta$-adrenergic receptor kinase activity is decreased, suggesting a previously unrecognized association between the degree of adrenergic activation and myocardial $\beta$-adrenergic receptor kinase expression. These data may have substantial relevance in clinical settings, since many patients are treated with such agents. Future studies aimed at the precise molecular mechanisms responsible for reduced $\beta$-adrenergic receptor kinase expression in the heart will provide data potentially useful for the management of adrenergic desensitization in clinical settings.

The heart appears to adapt in response to chronic $\beta$-adrenergic receptor antagonist administration in a manner that would be expected to offset reduced agonist stimulation. In many ways these adaptations appear to provide a desensitization-resistant state. The possibility that these adjustments may exist at the level of gene transcription of elements of the specific transduction pathway that they are aimed at interrupting is intriguing and suggests that homeostatic mechanisms play a role in the adaptive responses. It will be interesting to determine whether such changes are unique to the heart or instead reflect general features of adrenergic receptor function in many tissues.

\section{Acknowledgments}

The authors thank Matthew Spellman and Elisa Lynch for excellent technical support.

Dr. Ping and Dr. Kiel were supported by Institutional National Research Service Awards (HL07444 and CA09290, respectively). Dr. Hammond was supported by a Merit Award from the Veterans Affairs, by a National Institutes of Health Research Career Development Award (HL02812-01), and by the American Heart Association, California Affiliate (93-261). Dr. Hammond and Dr. Insel were also supported by a
Specialized Center of Research on Coronary and Vascular Diseases grant (HL-17682-18). Dr. Roth was supported by the American Heart Association, California Affiliate (90-69). Dr. Gelzer-Bell was funded through a Sarnoff Fellowship.

\section{References}

1. Brodde, O.-E. 1991. $\beta_{1}$ - and $\beta_{2}$-adrenoreceptors in the human heart: properties, function, and alterations in chronic heart failure. Pharmacol. Rev. 43:203242.

2. Benovic, J. L., F. Mayor, C. Staniszewski, R. Lef kowitz, and M. G. Caron. 1987. Purification and characterization of the $\beta$-adrenergic receptor kinase. $J$. Biol. Chem. 262:9026-9032.

3. Bristow, M. R., R. Ginsburg, W. Minobe, R. S. Cubiccioto, W. S. Sageman, K. Lurie, M. E. Billingham, D. C. Harrison, and E. G. Stinson. 1982. Decreased catecholamine sensitivity and $\beta$-adrenergic receptor density in failing human hearts. N. Engl. J. Med. 307:205-211.

4. Hammond, H. K., D. A. Roth, P. A. Insel, C. E. Ford, F. C. White, M. G Ziegler, A. S. Maisel, and C. M. Bloor. 1992. Myocardial $\beta$-adrenergic receptor expression and signal transduction after chronic volume overload hypertrophy and circulatory congestion in pigs. Circulation. 85:269-280.

5. Roth, D. A., K. Urasawa, G. A. Helmer, and H. K. Hammond. 1993. Down regulation of cardiac GTP-binding proteins in right atrium and left ventricle in pacing-induced congestive heart failure. J. Clin. Invest. 91:939-949.

6. Hadcock, J. R., and C. C. Malbon. 1988. Down-regulation of $\beta$-adrenergic receptors: agonist-induced reduction in receptor mRNA levels. Proc. Natl. Acad. Sci. USA. 85:5021-5025.

7. Feldman, A. M., A. E. Cates, W. B. Veazy, R. E. Hershberger, M. R. Bristow, K. L. Baughman, W. A. Baumgartner, and C. Van Dop. 1988. Increase in the 40,000 -mol wt pertussis toxin substrate (G-protein) in the failing human heart. J. Clin. Invest. 82:189-197.

8. Bohm, M., P. Gierschik, K. H. Jacobs, B. Pieske, P. Schnabel, M. Ungerer, and E. Erdmann. 1990. Increase of $\mathrm{Gi} \alpha$ in human hearts with dilated but not ischemic cardiomyopathy. Circulation. 82:1249-1265.

9. Longabaugh, J. P., D. E. Vatner. S. F. Vatner, and C. J. Homcy. 1988 Decreased stimulatory guanosine triphosphate binding protein in dogs with pressure-overload left ventricular failure. J. Clin. Invest. 81:420-424.

10. Hammond, H. K., L. A. Ransnas, and P. A. Insel. 1988. Noncoordinate regulation of cardiac Gs protein and $\beta$-adrenergic receptors by a physiological stimulus, chronic dynamic exercise. J. Clin. Invest. 82:2168-2171.

11. Muller, F. U., K. R. Boheler, T. Eschenhagen, W. Schmitz, and H. Scholz. 1993. Isoprenaline stimulates gene transcription of the inhibitory $\mathrm{G}$ protein $\alpha$ subunit $\mathrm{Gi} \alpha_{2}$ in rat heart. Circ. Res. 72:696-700.

12. Hadcock, J. R., J. D. Port, and C. C. Malbon. 1991. Cross-regulation between G-protein-mediated pathways. J. Biol. Chem. 266:11915-11922.

13. Horn, E. M., S. J. Corwin, S. F. Steinberg, Y. K. Chow, G. W. Neuberg, P. J. Cannon, E. R. Powers, and J. P. Bilezikian. 1988. Reduced lymphocyte stimulatory guanine nucleotide regulatory protein and $\beta$-adrenergic receptors in congestive heart failure and reversal with angiotensin converting enzyme inhibitor therapy. Circulation. 78:1373-1379.

14. Hammond, H. K., D. A. Roth, C. E. Ford, G. W. Stamnas, M. G. Ziegler, and C. Ennis. 1992. Myocardial adrenergic denervation supersensitivity depends upon a post-receptor mechanism not linked with increased cAMP production. Circulation. 85:666-679.

15. Bristow, M. R., W. A. Minobe. M. V. Reynolds, J. D. Port. R. Rasmussen. P. E. Ray, and A. M. Feldman. 1993. Reduced $\beta_{1}$-receptor mRNA abundance in the failing human heart. J. Clin. Invest. 92:2737-2745.

16. Ping, P., E. Lynch, and H. K. Hammond. 1993. Decreased $\beta_{1}$-adrenergic receptor mRNA in left ventricle following pacing-induced congestive heart failure. Circulation. 88:1-107.

17. Ungerer, M., M. Bohm, J. S. Elce, E. Erdmann, and M. J. Lohse. 1993. Altered expression of $\beta$-adrenergic receptor kinase $(\beta \mathrm{ARK})$ and $\beta_{1}$-adrenergic receptors in the failing human heart. Circulation. 87:454-461.

18. Ping, P., and H. K. Hammond. 1994. Diverse G-protein and $\beta$-adrenergic receptor mRNA expression in normal and failing porcine heart. Am. J. Physiol. 267:H2079-H2085.

19. Ping, P., G. A. Helmer, E. Lynch, C. M. Bloor, and H. K. Hammond. 1993. Pacing-induced congestive heart failure is associated with chamber specific down-regulation of Gs $\alpha$ and Gi $\alpha_{2}$ mRNA. Clin. Res. 41:144a. (Abstr.)

20. Hammond, H. K., D. A. Roth, M. D. McKirnan, and P. Ping. 1993. Regional myocardial down-regulation of the inhibitory GTP-binding protein $\left(\mathrm{Gi} \alpha_{2}\right)$ and $\beta$-adrenergic receptors in a porcine model for chronic episodic ischemia. J. Clin. Invest. 92:2644-2652.

21. Ungerer, M., G. Parruti, M. Bohm, M. Puzicha. A. DeBlasi, E. Erdmann, and M. J. Lohse. 1994. Expression of $\beta$-arrestins and $\beta$-adrenergic receptor kinases in the failing human heart. Circ. Res. 74:206-213.

22. Leopold, G., W. Ungethum, J. Pabst, Z. Simane, K. U. Buhring, and H. Wiemann. 1986. Pharmacodynamic profile of bisoprolol, a new $\beta_{1}$-selective adrenoceptor antagonist. Br. J. Clin. Pharmacol. 22:293-300. 
23. Hammond, H. K., F. C. White, L. Brunton, and J. C. Longhurst. 1987. Association of decreased myocardial receptors and chronotropic response to isoproterenol and exercise in pigs following chronic dynamic exercise. Circ. Res. 60:720-726.

24. Bradford, M. M. 1976. A rapid and sensitive method for the quantification of microgram quantities of protein utilizing the principle of protein dye binding. Anal. Biochem. 72:248-254.

25. Salomon, Y., C. Londos, and M. Rodbell. 1974. A highly sensitive adenylate cyclase assay. Anal. Biochem. 58:541-548.

26. Nagai, K., and H. C. Thogersen. 1984. Generation of $\beta$-globin by sequence specific proteolysis of a hybrid protein produced in Escherichia coli. Nature (Lond.). 309:810-812.

27. Towbin, H., S. Theophil, and J. Gordan. 1979. Electrophoretic transfer of proteins from polyacrylamide gels to nitro-cellolose sheets: procedure and some applications. Proc. Natl. Acad. Sci. USA 76:2258-2262.

28. Chomczynski, P., and N. Sacchi. 1987. Single-step method of RNA isolation by acid guanidinium thiocyanate-phenol-chloroform extraction. Anal. Biochem. 162:156-159.

29. Benovic, J. L. 1991. Purification and characterization of $\beta$-adrenergic receptor kinase. Methods Enzymol. 200:351-363.

30. Garcia-Higuera, I., and F. Major. 1992. Rapid agonist-induced $\beta$-adrenergic receptor kinase translocation in C6 glioma cells. FEBS (Fed. Eur. Biochem. Soc.) Lett. 302:61-64.

31. Roth, D. A., K. Urasawa, D. Leiber, Insel P. A., and H. K. Hammond. 1992. A substantial proportion of cardiac $G$ s is not associated with the plasma membrane. FEBS (Fed. Eur. Biochem. Soc.) Lett. 296:46-50.
32. Weinstein, L. S., A. M. Spiegel, and A. D. Carter. 1988. Cloning and characterization of the human gene of the $\alpha$-subunit of $\mathrm{Gi}_{2}$, a GTP-binding signal transducing protein. FEBS (Fed. Eur. Biochem. Soc.). Lett. 232:333-340.

33. Kozasa, T., I. Hiroshi, T. Tsukamoto, and Y. Kaziro. 1988. Isolation and characterization of the human Gs $\alpha$ gene. Proc. Natl. Acad. Sci. USA. 85:20812085.

34. Karliner, J. S., M. B. Stevens, N. Honbo, and J. I. E. Hoffman. 1989. Effects of acute ischemia in the dog on myocardial blood flow, beta receptors, and adenylate cyclase activity with an without chronic beta blockade. J. Clin. Invest. 83:474-481.

35. Marquetant, R., B. Brehm, and R. H. Strasser. 1992. Chronic $\beta$-blockade transregulates inhibitory $A_{1}$ adenosine receptors and muscarinic $M_{2}$ receptors of the adenylyl cyclase system. J. Mol. Cell. Cardiol. 24:535-548.

36. Morris, S. A., G. Florant, M. Saxon, G. Chen, and J. P. Bilezikian. 1993. Adaptations of myocardial $\beta$-adrenergic receptor complex in hibernating marmots. Am. J. Physiol. 265:R1430-R1438.

37. Ping, P., D. Kiel, K. D. Sumida, E. Lynch, P. A. Insel, and H. K. Hammond. 1994. Cardiac $\beta$-adrenergic receptor kinase activity reflects levels of adrenergic receptor activation in vivo. Clin. Res. 42:334a. (Abstr.)

38. Inglese, J., N. J. Freedman, W. J. Koch, and R. J. Lef kowitz. 1993. Structure and mechanism of the $\mathrm{G}$ protein-coupled receptor kinases. J. Biol. Chem. 268:23735-23738.

39. Zhou, X.-M. and P. H. Fishman. 1991. Desensitization of the human $\beta_{1-}$ adrenergic receptor: involvement of the cyclic AMP-dependent but not a receptorspecific protein kinase. J. Biol. Chem. 266:7462-7468.

40. Penn, R. B., and J. L. Benovic. 1994. Structure of the human gene encoding the $\beta$-adrenergic receptor kinase. J. Biol. Chem. 269:14924-14930. 